\title{
KOMUNIKASI IBU DAN ANAK DENGAN DEPRESI PADA REMAJA
}

\author{
Ariza Cilvia Nora \& Erlina Listyanti Widuri \\ Fakultas Psikologi \\ Universitas Ahmad Dahlan \\ Jalan Kapas No. 9 Yogyakarta \\ erlina_psiuad@yahoo.co.id
}

\begin{abstract}
This study aims to determine the relationship between mother and child communication with depression in adolescents. Samples of this study were students of 'Sekolah Menengah Kejuruan Negeri 02' Depok (Sleman), Yogyakarta, 17-18 years old and living with parents. The numbers of samples in this study were 90 people. Quantitative analysis was carried out using quantitative method; data was retrieved using a scale of depression in adolescent and maternal and child communication scale. Data analysis techniques used was the Pearson correlation. The analysis indicated a highly significant negative relationship between maternal communication and children with depression in adolescents, with a correlation coefficient $(\mathrm{r})=$ -0.325 with $(\mathrm{p})=0.002(\mathrm{p}<0.01)$. Maternal communication and children contributed in influencing depression in adolescents was $10.5 \%$. Based on research that has been done, the researcher concluded that there was a highly significant negative relationship between maternal communication and children with depression in adolescents. The better communication is done on the child's mother, the smaller the occurrence of depression in adolescents, whereas the lack of communication on the child's mothers, the greater occurrence of depression in adolescents.
\end{abstract}

Keywords: Adolescents, depression, Maternal and Child Communication.

\begin{abstract}
Abstrak
Penelitian ini bertujuan untuk mengetahui hubungan antara komunikasi ibu dan anak dengan depresi pada remaja. Sampel penelitian ini adalah siswa Sekolah Menengah Kejuruan Negeri 02 Depok (Sleman), Yogyakarta yang berusia 17-18 tahun dan tinggal bersama orang tua (ibu bapak). Jumlah sampel pada penelitian ini adalah 90 orang. Pengambilan
\end{abstract}


sampel menggunakan teknik cluster random sampling. Metode pengumpulan data yang digunakan adalah metode kuantitatif, data berupa skor diperoleh dengan menggunakan skala depresi pada remaja dan skala komunikasi ibu dan anak. Teknik analisis data yang digunakan adalah analisis korelasi product moment dari pearson dengan bantuan komputasi statistik program SPSS 16,0 for Windows. Hasil analisis menunjukkan adanya hubungan negatif yang sangat signifikan antara komunikasi ibu dan anak dengan depresi pada remaja, dengan koefisien korelasi $(\mathrm{r})=-0,325$ dengan $(\mathrm{p})=0,002(\mathrm{p}<0,01)$. Variabel komunikasi ibu dan remaja memberikan sumbangan efektif sebesar 10,5\% dalam mempengaruhi depresi pada remaja. Berdasarkan penelitian yang sudah dilakukan, peneliti menyimpulkan bahwa ada hubungan negatif yang sangat signifikan antara komunikasi ibu dan anak dengan depresi pada remaja. Semakin baik komunikasi yang dilakukan ibu pada anak maka semakin kecil terjadinya depresi pada remaja, sebaliknya semakin kurang komunikasi ibu pada anak maka semakin besar terjadinya depresi pada remaja.

Kata Kunci : Depresi, Komunikasi Ibu dan Anak, Remaja.

\section{Pendahuluan}

Kemajuan zaman dan teknologi tidak dapat dihindari oleh siapapun, termasuk remaja. Chaplin (Kartono, 2004) mengatakan bahwa batasan usia remaja antara laki-laki dan perempuan berbeda. Masa remaja bagi perempuan berlangsung dari 12 sampai 21 tahun, perempuan lebih cepat mengalami kematangan seksual daripada laki-laki. Masa remaja laki-laki berlangsung dari usia 13 sampai 22 tahun.

Remaja memilikiemosi yang masih labil, dan remaja selalu ingin tahu dan mencoba hal-hal yang baru dan menantang. Seorang remaja perlu mendapatkan pengawasan, perhatian dan kasih sayang yang lebih dari orang tua maupun orang yang ada di sekitarnya, tetapi tidak dengan mengekangnya melainkan tetap diberi kepercayaan dan kebebasan yang telah disepakati batasannya. Jika pada masa remaja anak kurang mendapatkan perhatian dan kasih sayang maka tidak sedikit remaja yang terjebak dalam hal-hal yang bersifat negatif seperti penggunaan obat-obatan atau menjadi pecandu narkoba, tawuran, bolos sekolah, pergaulan bebas dan lain-lain.

Remaja berusaha untuk melepaskan diri dari orang tua dengan maksud untuk menemukan dirinya. Erikson (Monks dkk,1992) menamakan proses tersebut sebagai proses mencari identitas diri. Kebanyakan dari remaja pernah mengalami periode 
kesedihan dari waktu ke waktu. Remaja dapat merasa sangat terpuruk, memiliki rasa sedih luar biasa, kehilangan minat pada berbagai hal, sulit untuk berkonsentrasi, mengharap hal terburuk akan terjadi, atau bahkan mempertimbangkan untuk bunuh diri. Gangguan mood ini bersifat unipolar dan gangguan ini sering disebut depresi. Depresi sering disebut gangguan mood atau gangguan suasana perasaan karena terdapat kondisi emosi negatif yang kompleks seperti kesedihan, kecemasan, kemarahan, dan rasa bersalah.

Suasana perasaan manusia ini dipengaruhi oleh hal-hal yang ada dalam dirinya dan stimulus dari luar dirinya. Data dari survei yang dilakukan oleh Direktorat Kesehatan Jiwa tahun 1996 di 10 kota pada 1.994 responden dengan menggunakan instrumen diagnostik gangguan jiwa dari WHO, menemukan bahwa 17,25\% atau 344 responden merupakan kasus ganguan jiwa, dan 4,1\% atau 82 orang menderita depresi. Prediksi WHO dalam dua dekade mendatang diperkirakan lebih dari 300 juta penduduk dunia menderita depresi. Tahun 2020, depresi akan menempati masalah kesehatan nomor dua terbesar setelah penyakit kardiovaskuler (Thabrany dan Pujianto, 2002).

Depresi dapat terjadi pada siapa saja dalam berbagai rentang usia mulai dari anak-anak, remaja, dewasa maupun orang tua. Orang muda yang berusia antara 15-24 tahun sangat beresiko menderita depresi. Menurut Brooks dan Peterson (Dancey \& Kenney, 1997) sekitar 5\% remaja menderita depresi tingkat tinggi, 1015\% depresi sedang, 20-30\% depresi ringan. Simtom depresi ini akan serius pada orang dewasa. Berdasarkan survei yang dilakukan oleh Avenoli \& Steinberg (Steinberg, 2002) kira-kira 25\% remaja merasakan munculnya depresi dan 3\% sudah masuk kategori depresi klinis.

Dahulu depresi hanya dapat dijumpai pada orang dewasa, namun saat ini depresi dapat dijumpai pada remaja. Depresi pada anak dan remaja biasanya dianggap sebagai gangguan mood yang normal pada fase perkembangan. Keraguan ini disebabkan karena anak dan remaja dianggap belum matang secara psikologis dan kognitif (Anonymus, 2007).

Menurut Rice (1999), depresi adalah gangguan mood, kondisi emosional berkepanjangan yang mewarnai seluruh proses mental (berpikir, berperasaan dan berperilaku) seseorang. Pada umumnya mood yang secara dominan muncul adalah perasaan tidak berdaya dan kehilangan harapan.

Depresi sering dianggap sebagai gangguan afektif karena adanya ciri yang menonjol, yaitu keadaan suasana hati (emosi) yang tertekan (Beck dalam Dacey dan Kenny, 1997). Supratiknya (2002) mengatakan depresi merupakan gangguan afektif 
(mood) yang bersifat ekstrim dan tidak sesuai, meliputi : kegembiraan (elation) dan kesedihan (depression) yang ekstrim seperti : berteriak dengan histeris, murung atau jadi sangat pendiam dan pasif, keinginan untuk bunuh diri, dan meningkatkan ketergantungan pada bantuan orang lain.

Individu yang mengalami depresi cenderung untuk mengembangkan pemikiran yang menyimpang dan hanya memperhatikan atau mengingat aspek negatif pengalaman dari pada segi positifnya (Beck dalam Greenberger, 2004). Cara berpikir individu yang tidak realistis dan cenderung menyalahkan dirinya sendiri menyebabkan terjadinya penyimpangan kognitif terhadap dirinya, dunia (lingkungan), dan masa depannya. Individu tersebut mengevaluasi dan menginterpretasi hal-hal yang terjadi secara negatif dan cenderung mengambil kesimpulan tidak tepat sehingga pandangannya negatif (Beck dalam Greenberger \& Padesky, 2004).

Menurut Chaplin (1997) depresi dibagi menjadi dua pengertian. Pertama adalah pada orang normal, depresi merupakan keadaan kemurungan (kesedihan, patah semangat) yang ditandai dengan perasaan tidak pas, menurunnya kegiatan dan pesimisme menghadapi masa yang akan datang. Pengertian yang kedua adalah pada kasus patologis, dimana depresi merupakan ketidakmauan yang ekstrim untuk mereaksi pada stimulus disertai dengan menurunnya nilai diri, delusi, ketidakpastian, tidak mampu dan putus asa.

Depresi biasanya terjadi saat stres yang dialami oleh seseorang tidak kunjung reda, depresi yang dialami berkolerasi dengan kejadian dramatis yang menimpa seseorang seperti kematian seseorang, kehilangan pekerjaan, komunikasi yang kurang efektif antara satu dengan yang lain (Rice,1999). Pendapat para ahli tentang depresi di atas menunjukkan bahwa depresi itu bisa terjadi pada siapa saja. Setiap orang pasti akan merasakan saat-saat sedih, lesu, dan kadang tidak bergairah, inilah yang disebut gangguan perasaan. Keadaan ini merupakan reaksi yang normal terhadap stres kehidupan. Gangguan perasaan itu bila dibiarkan sampai pada tahap atau waktu tertentu maka akan menjadi gangguan depresi yang sifatnya tidak normal.

Depresi pada penelitian ini menekankan pada depresi yang terjadi pada orang normal. Depresi yang terjadi pada orang normal ini dapat dilihat gejalanya seperti aktivitas menurun, selalu merasa sedih tanpa ada alasan yang jelas, pola tidur yang terganggu, serta berpikir pesimis terhadap masa depan. Penderita depresi mempunyai negatif self scema (skema diri negatif) atau dipresogenic schemata yaitu pola berpikir negatif dalam menginterpretasikan sesuatu atau peristiwa baik yang dialami secara nyata maupun tidak nyata, bila yang menekan negatif life event maka ada kecenderungan untuk berkembang ke arah pola berpikir yang menyimpang (cognitif 
distortions). Pola berpikir menyimpang pada penderita depresi meliputi pandangan negatif tentang diri, dunia dan masa depannya yang dikenal dengan "tri tunggal pola pikir negatif'.

Ciri-ciri orang yang mengalami depresi dapat dilihat dari cara berpikir, perasaan dan sampai kepada bentuk perilaku. Adapun ciri-ciri depresi berdasarkan DSMIVTR (APA, 2000) sebagai berikut :

a. Perubahan pada mood

Perubahan pada mood (periode terus menerus dari perasaan terpuruk, sedih, atau muram menangis yang berlebihan. Meningkatnya iritabilitas (mudah tersinggung), kegelisahan, atau kehilangan kesabaran.

b. Perubahan dalam motivasi

Perasaan tidak termotivasi, atau memiliki kesulitan untuk memulai (kegiatan) sehari-hari, menurunnya tingkat partisipasi sosial atau minat dalam aktifitas menyenangkan bahkan gagal untuk merespon pada pujian dan menarik diri dari kehidupan yang biasa dijalaninnya.

c. Perubahan dalam fungsi dan perilaku motorik

Remaja bergerak atau berbicara dengan lebih perlahan daripada biasanya, perubahan dalam kebiasaan tidur (terlalu banyak tidur atau sedikit tidur), adanya perubahan dalam selera makan (makan terlalu banyak atau makan terlalu sedikit), adanya perubahan dalam berat badan serta berfungsi kurang efektif daripada biasanya di tempat kerja atau di sekolah.

d. Perubahan kognitif

Adanya perubahan kognitif yang muncul pada remaja antara lain sulitnya untuk berkonsentrasi atau berpikir jernih, berpikir negatif mengenai diri sendiri dan juga masa depannya, adanya perasaan bersalah dan menyesal mengenai kesalahan masa lalu, kurangnya self esteem , bahkan berpikir terhadap kematian atau bunuh diri.

Depresi itu sendiri terdiri dari banyak gejala tidak hanya penyimpangan suasana hati. Beck (1985) mengemukakan depresi sebagai suatu keadaan dengan ciri sebagai berikut :

a. Perubahan suasana hati yang spesifik, seperti kesedihan, kesepian, dan apatis.

b. Keinginan-keinginan menghukum diri sendiri, seperti keinginan untuk menghindar, bersembunyi, keinginan untuk bunuh diri.

c. Konsep diri negatif yang berhubungan dengan penyalahan diri dan mencela diri.

d. Perubahan dalam fungsi fisik, seperti anoreksia, insomnia, hipersomnia dan hilangnya nafsu makan.

e. Perubahan dalam tingkat aktifitas, seperti menurunnya aktifitas motorik ataupun 
mudah merasa lelah.

Selain ciri-ciri umum pada depresi juga terdapat ciri-ciri klinis sebagai berikut sulit tidur, kehilangan nafsu makan, atau keinginan makan terus, lesu, menarik diri dari pergaulan, mudah tersinggung, cepat letih, membenci diri sendiri, dan berpikir untuk bunuh diri. Depresi seperti ini dapat menghalangi penyembuhan atau rehabilitasi bagi penderitanya, bahkan dapat mengarah pada kematian akibat bunuh diri (Vitahealt, 2003).

Rice (Fadillah, 2001) mengatakan bahwa ciri-ciri yang dimunculkan akibat depresi mencakup tiga aspek kehidupan yaitu, aspek fisik, psikis, dan sosial. Individu yang terkena depresi pada umumnya menunjukkan ciri psikis, fisik dan sosial yang khas, seperti murung, sedih berkepanjangan, sensitif, mudah marah, dan tersinggung, semangat hilang, hilangnya rasa percaya diri, kurang dapat berkonsentrasi dan daya tahan menurun.

\section{a. Ciri Fisik}

Menurut beberapa ahli, ciri depresi yang kelihatan ini mempunyai rentangan dan variasi yang luas sesuai dengan berat ringannya depresi yang dialami. Namun secara garis besar ada beberapa gejala fisik umum yang relatif mudah dideteksi, seperti

1) Gangguan pola tidur (sulit tidur, terlalu banyak atau terlalu sedikit)

2) Menurunnya tingkat aktivitas, aktivitas lebih banyak dilakukan tanpa melibatkan banyak orang lain.

3) Menurunnya efisiensi belajar. Remaja yang terkena depresi akan sulit memfokuskan perhatian atau pikiran pada suatu hal. Sehingga, remaja juga akan sulit memfokuskan energi pada hal-hal prioritas. Kebanyakan yang dilakukan justru hal-hal yang tidak efisien dan tidak berguna, seperti : melamun, merokok terus menerus, sering menelpon yang tak perlu. Remaja yang terkena depresi akan dapat dilihat dari metode belajarnya yang menjadi kurang terstruktur, sistematika belajarnya jadi kacau.

4) Menurunnya produktivitas kerja. Remaja yang terkena depresi akan kehilangan sebagian atau seluruh motivasinya. Sebabnya, tidak lagi bisa menikmati dan merasakan kepuasan atas apa yang dilakukannya. Oleh karena itu, keharusan untuk tetap beraktivitas membuatnya semakin kehilangan energi karena energi yang ada sudah banyak terpakai untuk mempertahankan diri agar tetap dapat berfungsi seperti biasanya. Remaja mudah sekali lelah, capai padahal belum melakukan aktivitas yang berarti.

5) Mudah merasa letih dan sakit. Jelas depresi itu sendiri adalah perasaan negatif. Jika seseorang menyimpan perasaan negatif maka jelas akan 
membuat letih karena membebani pikiran dan perasaan dan harus memikulnya dimana saja dan kapan saja, suka tidak suka.

\section{b. Ciri Psikis}

1) Kehilangan rasa percaya diri. Penyebabnya remaja yang mengalami depresi cenderung memandang segala sesuatu dari sisi negatif, termasuk menilai diri sendiri. Remaja senang sekali membandingkan antara dirinya dengan orang lain. Orang lain dinilai lebih sukses, pandai, beruntung, kaya, lebih berpengalaman, lebih diperhatikan oleh guru, dan pikiran negatif lainnya.

2) Sensitif. Remaja yang mengalami depresi senang sekali mengkaitkan segala sesuatu dengan dirinya. Perasaannya sensitif sekali, sehingga sering peristiwa yang netral dipandang dari sudut pandang yang berbeda oleh remaja bahkan salah paham. Akibatnya, remaja mudah tersinggung, mudah marah, perasa, curiga akan maksud orang lain (yang sebenarnya tidak ada apa-apa), mudah sedih, murung, dan lebih suka menyendiri.

3) Merasa diri tidak berguna. Perasaan tidak berguna ini muncul karena remaja merasa menjadi orang yang gagal terutama di bidang atau lingkungan yang seharusnya remaja kuasai dan pahami.

4) Perasaan bersalah. Perasaan bersalah terkadang timbul dalam pemikiran remaja yang mengalami depresi. Remaja memandang suatu kejadian yang menimpa dirinya sebagai suatu hukuman atau akibat dari kegagalan remaja melaksanakan tanggung jawab yang seharusnya dikerjakan. Banyak pula yang merasa dirinya menjadi beban bagi orang lain dan menyalahkan diri atas situasi tersebut.

5) Perasaan terbebani. Banyak remaja yang menyalahkan orang lain atas kesusahan yang dialaminya. Remaja merasa terbebani karena merasa terlalu dibebani tanggung jawab yang berat.

\section{c. Ciri Sosial}

Problem sosial yang terjadi biasanya berkisar pada masalah interaksi dengan keluarga, teman, masyarakat. Masalah ini tidak hanya berbentuk konflik, namun masalah lainnya juga seperti perasaan minder, malu, cemas jika berada di antara kelompok dan merasa tidak nyaman untuk berkomunikasi secara normal. Remaja merasa tidak mampu untuk bersikap terbuka dan secara aktif menjalin hubungan dengan lingkungan sekalipun ada kesempatan.

Berdasarkan ciri-ciri di atas, depresi terjadi bukan saja karena adanya penyimpangan perasaan tetapi adanya ciri-ciri lain yang dapat mempengaruhi depresi yaitu fisik, psikis dan sosial. Remaja yang mengalami depresiakan terjadi perubahan pada fisiknya (berat badan yang naik turun, mudah letih dan lesu, 
gangguan tidur serta aktifitas yang berhubungan dengan fisik menurun), sedangkan pada keadaan psikis remaja depresi dapat dilihat mudah tersinggung, berpikir negatif, tidak percaya diri, susah konsentrasi, untuk keadaan sosial, remaja yang depresi akan cenderung menjauhkan diri dari aktifitas yang banyak melibatkan orang banyak, menghindari komunikasi dengan orang lain, dan sering konflik dengan lingkungannya.

Ciri-ciri tersebut menunjukkan depresi yang dapat diderita oleh orang normal, sedangkan ciri-ciri yang diderita oleh orang klinis sifatnya lebih ekstrim seperti adanya rasa benci, putus asa, marah yang luar biasa terhadap dirinya bahkan melakukan tindakan bunuh diri.

Ada beberapa faktor penyebab depresi yang sudah diteliti oleh beberapa ahli (Santrock, 2003) yaitu :

a. Ikatan antara ibu dan anak yang tidak memberikan rasa aman, tidak adanya cinta dan kasih sayang dalam pengasuhan anak, dalam hal ini ibu tidak melakukan komunikasi yang baik untuk dapat memberikan, menyampaikan bentuk kasih sayangnya pada anak, atau kehilangan salah satu orang tua pada masa kanakkanaknya, sehingga menciptakan set kognitif negatif.

b. Pada sebuah penelitian longitudinal yang dilakukan oleh Gjerde \& Block tahun 1990 (Gjerde \& Block dalam Santrock, 2003) terhadap anak-anak nonklinis, dipelajari hubungan antara interaksi orang tua dan anak selama masa prasekolah dengan sindrom depresi yang muncul ketika usia 18 tahun. Hasil yang signifikan ditemukan hanya pada interaksi antara ibu dan anak perempuan. Bila ibu menerapkan kombinasi pola otoriter dan pengasuhan dengan kasih sayang di awal masa kanak-kanak, pada usia 18 tahun anak perempuannya akan cenderung memperlihatkan depresi. Pada situasi dengan "standar ganda" seperti ini, anak-anak perempuan tidak diberi kesempatan untuk bergerak dari hubungan ibu dan anak perempuan menuju hubungan dengan dunia luas dimana anak harus mandiri dan bisa mengatur dirinya sendiri.

c. Memiliki orang tua yang mengalami depresi termasuk salah satu faktor utama yang memungkinkan munculnya depresi dimasa kanak-kanak, dan pengalaman ini akan dibawa terus hingga masa remaja. Orang tua yang tidak hadir secara emosional, terlibat dalam konflik perkawinan dan memiliki masalah ekonomi dapat juga memunculkan depresi pada remaja.

d. Penelitian Venberg pada tahun 1990 (Venberg dalam Santrock, 2003) terbatasnya hubungan dengan teman sebaya, ketiadaan hubungan yang dekat dengan seorang sahabat akan memunculkan depresi pada remaja karena pada masa remaja adalah masa dimana pertemanan adalah segala-galanya dengan adanya teman, remaja dapat berbagi apa saja yang menjadi permasalahannya

Rice (1999) mengatakan bahwa salah satu penyebab terjadinya depresi adalah 
komunikasi interpersonal yang tidak efektif. Komunikasi yang demikian sering terjadi di dalam lingkungan keluarga. Lingkungan keluarga merupakan tempat anak berawal tumbuh secara jasmani dan membentuk kepribadian. Dalam lingkungan tersebut anak melakukan komunikasi dengan anggota keluarga lainnya seperti ayah, ibu dan saudara. Anak lebih banyak berkomunikasi dengan ibu daripada dengan ayah. Ini dikarenakan yang lebih banyak terlibat aktifitas di dalam rumah adalah ibu, sedangkan ayah lebih banyak menghabiskan waktunya di luar rumah.

Komunikasi interpersonal dapat terjadi antara ibu dan anak sebagaimana yang dikemukakan oleh Durkin (1995) komunikasi yang dilakukan anak dengan ibunya cenderung berkaitan dengan masalah interpersonal, sedangkan komunikasi dengan ayah cenderung berkaitan dengan persiapan anak menghadapi dunia luar.

Komunikasi adalah suatu proses penyampaian informasi (pesan, ide, gagasan) dari satu pihak kepada pihak lain agar terjadi saling mempengaruhi di antara keduanya. Pada umumnya, komunikasi dilakukan dengan menggunakan kata-kata (lisan) yang dapat dimengerti oleh kedua belah pihak. Apabila tidak ada bahasa verbal yang dapat dimengerti oleh keduanya, komunikasi masih dapat dilakukan dengan menggunakan gerak-gerik badan, menunjukkan sikap tertentu, misalnya tersenyum, menggelengkan kepala, mengangkat bahu. Cara seperti ini disebut komunikasi dengan bahasa nonverbal (Wikipedia, komunikasi, 2008).

Pada umumnya individu menghabiskan sekitar 50\% sampai dengan 70\% untuk berkomunikasi baik itu dengan tulisan, tatap muka maupun melalui telepon. Catatan yang perlu diperhatikan $80 \%$ komunikasi yang dilakukan dengan berbicara apa yang dikatakan dan bagaimana mengatakan akan sangat menentukan kesuksesan dan kualitas kehidupan individu (Cole, 1997). Memahami tentang komunikasi berarti melihat bentuk komunikasi yang lebih akrab di dalam berinteraksi antar individu karena komunikasi yang terjalin tidak hanya sebatas saling bertukar informasi, juga memerlukan keterbukaan dan keterusterangan dengan menyampaikan, menilai maupun bersikap apa adanya, dengan memberi peluang untuk lebih saling mengenal sehingga tumbuh rasa hormat, respek, dan simpati karena komunikasi dilakukan oleh individu yang memiliki perbedaan antar pribadi dan kebutuhan harga diri dan ingin mendapat pengakuan dari orang lain (Halloran dalam Liliweri, 1997).

Ibu adalah orang tua perempuan seorang anak, baik melalui hubungan biologis maupun sosial. Umumnya ibu memiliki peranan yang sangat penting dalam membesarkan anak, dan panggilan ibu dapat diberikan untuk perempuan yang bukan orang tua kandung (biologis) dari seseorang yang mengisi peranan ini. Contohnya adalah pada orang tua angkat (karena adopsi) atau ibu tiri (istri ayah biologis anak). Ibu yang lebih sering mengadakan komunikasi dengan anak ketimbang ayah 
yang lebih banyak beraktifitas di luar, dapat menjadi orang tua dan sekaligus teman yang baik bagi anak untuk berbagi permasalahan, kasih sayang dan hal-hal yang disenangi oleh anak.

Dalam keluarga ibu yang bersikap lebih menerima, lebihmengerti, lebih koperatif terhadap anak dibandingkan dengan ayah, meskipun ibu seperti juga ayah dapat menunjukkan otoritasnya bila persoalan mengenai hal-hal yang prinsip (Younis dan Smollar dalam Monk dkk, 1992). Hal itu sesuai dengan peranan ibu, antara lain sebagai pemberi rasa aman, kasih sayang, tempat curahan hati dan pengatur kehidupan rumah tangga, dengan kata lain ibu lebih menaruh perhatian dan lebih aktif dalam perkembangan remaja.

Komunikasi yang dilakukan ibu pada anaknya tidak jarang terkadang ada unsur-unsur pemaksaan keinginan agar anak dapat menjadi lebih sempurna dalam segala aspek kehidupannya, sehingga anak merasa tidak dihargai dan tertekan dalam menjalankan kehidupannya. Tuntutan berprestasi yang optimal baik di sekolah maupun di lingkungan sosial lainnya, pergaulan yang terkadang jauh dari norma-norma masyarakat sehingga membuat orang tua ekstra ketat untuk membangun kewaspadaan dalam mengasuh anak, permasalahan dengan teman maupun pacar, bahkan pengekangan-pengekangan yang membuat remaja tidak nyaman untuk menjalankan hidupnya merupakan bentuk stresor yang berat dihadapi remaja. Untuk itu perlu di dalam komunikasi ada cara atau teknik agar antara ibu dan anak tidak terjadi kesenjangan harapan dan realita yang akan diungkap.

Komunikasi secara etimologis atau menurut asal katanya adalah dari bahasa Latin communicatus, dan perkataan ini bersumber pada kata communis. Kata communis ini memiliki makna "berbagi" atau "menjadi milik bersama" yaitu suatu usaha yang memiliki tujuan untuk kebersamaan atau kesamaan makna.

Memahami tentang komunikasi berarti melihat bentuk komunikasi yang lebih akrab di dalam berinteraksi antar individu karena komunikasi yang terjalin tidak hanya sebatas saling bertukar informasi juga memerlukan keterbukaan dan keterusterangan dengan menyampaikan, menilai ataupun bersikap apa adanya. Memberikan peluang untuk lebih saling mengenal sehingga tumbuh rasa hormat, respek dan simpati karena komunikasi dilakukan oleh individu yang memiliki perbedaan antar pribadi dan kebutuhan harga diri dan ingin mendapatkan pengakuan dari orang lain (Halloran dalam Liliweri,1997).

Komunikasi pertama yang dilakukan anak adalah komunikasi dalam lingkungan keluarga, termasuk di dalamnya adalah komunikasi antara anak dan ibu. Menurut Panut dan Ida (1999), di dalam keluarga anak cenderung lebih banyak mengkomuni- 
kasikan masalah sehari-hari kepada ibu, karena ibu sebagai orang yang paling berperan dalam pengasuhan anak sehingga memungkinkan ibu lebih intens berinteraksi bersama anaknya.

Hawari (1991) mengatakan bahwa komunikasi antara ibu dan anak adalah komunikasi yang melibatkan unsur-unsur penerimaan, kehangatan, dan kasih sayang sehingga membentuk saling pengertian antara ibu dan anak. Komunikasi yang dilakukan anak dengan ibu di dalam keluarga tentang pengalaman sehari-hari sangatlah penting, sehubungan dengan pesatnya perkembangan yang dialami anak, masalah dan kesulitan banyak muncul dalam diri anak. Bagaimana cara anak mengatasi masalah, dapat menerima kekurangan pada dirinya, bagaimana anak dapat memanfaatkan waktu dengan baik dan bersemangat dalam menjalani hidup penting dipahami anak dengan cara berkomunikasi secara lancar, nyaman, dan akrab dengan ibu (Fuad, 2005).

De Vito (1995) mengungkapkan aspek-aspek komunikasi yaitu:

a. Keterbukaan (oppeness), keterbukaan memiliki tiga aspek yaitu:

1) Keinginan memiliki diri(memberi informasi tentang diri kepada orang lain). Di dalam keluarga ditunjukkan pada sikap anak yang selalu memberikan informasi tentang dirinya sendiri kepada orang tuanya terutama pada ibu yang biasanya dianggap paling dekat dengan anak, begitu pula sebaliknya.

2) Keinginan untuk memberi reaksi secara jujur terhadap pesan-pesan dari orang lain (secara spontan tanpa dalih terhadap umpan balik dari orang lain). Di dalam lingkup keluarga ditunjukkan dengan adanya keinginan dari anak itu sendiri untuk memberikan reaksi secara jujur terhadap pesanpesan yang disampaikan orang tuanya begitu pula sebaliknya.

3) Mengakui bahwa perasaan dan pikiran yang diekspresikan merupakan milik diri sendiri yang mampu dipertanggungjawabkan, serta tidak berusaha untuk memindahkan tanggung jawab akan perasaan diri sendiri kepada orang lain. Di dalam keluarga baik anak maupun ibu sebagai orang tua mengakui terhadap pikiran, perasaan, dan perbuatan yang dilakukan beserta tanggung jawab dibelakangnya tanpa menghindari dan menuduh atau memindahkannya ke orang lain.

b. Empati (Empaty), merupakan kemampuan untuk merasakan setiap apa yang dialami atau dirasakan oleh orang lain tanpa kehilangan identitas sendiri. Berempati di dalam keluarga terlihat pada remaja yang selalu dapat merasakan apa yang dirasakan ibu dalam pikiran dan tindakannya serta anak dapat merasakan apa yang ibu alami seperti dia mengalaminya sendiritanpa kehilangan identitasnya sebagai anak yang harus membantu dan bertanggung jawab terhadap dirinya.

c. Dukungan (supportivenes)

1) Lebih bersifat deskriptif daripada evaluatif, karena pernyataan yang evaluatif 
membuat lawan bicara banyak membela diri.

2) Lebih banyak bersifat sementara daripada pasti. Pernyataan seperti ini dikeluarkan oleh seseorang yang memiliki pikiran dan sikap terbuka serta keinginan untuk mendengarkan pandangan orang lain yang berlawanan dengan pandangan diri sendiri. Di dalam keluarga antara ibu dan anak saling mendukung terhadap pikiran serta tindakan yang akan dilakukan, selama itu dianggap baik oleh kedua belah pihak.

d. Kepositifan (positiviness)

1) Menunjukkan sikap positif (penghargaan pada diri sendiri, orang lain dan situasi komunikasi secara umum, dalam pola hubungan antara ibu dan anak terlihat adanya cara menghargai diri sendiri sebagai anak dan menghargai ibu juga sebagai pihak yang cukup dekat dengan dirinya, serta menghargai komunikasi yang dilakukan dengan ibu begitu pula sebaliknya.

2) Memuji lawan bicara, anak memuji ibu sebagai lawan bicara begitu pula sebaliknya ibu juga memuji anak sebagai lawan bicara supaya tercipta suatu suasana yang nyaman antara keduanya.

e. Kesamaan (similarity)

Komunikasi dengan kesetaraan tidak mengharuskan anak untuk selalu menerima dan menyetujui perkataan dan perilaku ibu. Secara umum, permintaan anak harus disampaikan secara sopan sehingga ibu dapat memahaminya sebagai suatu kebutuhan, bukan dengan cara menuntut ibunya. Bagi ibu tidak menampakkan superioritasnya sebagai orangtua yang berhak mengatur anaknya dan selalu menang.

Masalah depresi yang dialami remaja bisa multifaktor, namun dalam penelitian ini fokus faktor yang menjadikan remaja depresi terletak pada komunikasi yang dilakukan antara ibu dan anak. Melakukan komunikasi dengan ibu tentang pengalaman sehari-hari bagi anak sangatlah penting, karena akan mengurangi stresor yang dihadapi anak. Pesatnya perkembangan yang dialami anak dalam masa remaja akan menimbulkan dinamika tersendiri bagi anak. Antara ibu dan anak tidak terdapat kesenjangan yang drastis, adanya kesetaraan ini memungkinkan tidak adanya superioritas antara ibu dan anak (De Vito, 1995).

Komunikasi yang dilakukan ibu pada anak menurut De Vito (1995) melibatkan lima aspek komunikasi. Pertama keterbukaan (oppeness) dengan adanya keterbukaan antara ibu dan anak, anak dapat terbuka dalam pikiran dan perasaan yang dihadapinya kepada ibu sehingga komunikasi yang dilakukan dapat berjalan secara jujur dan bertanggungjawab. Anak yang melakukan komunikasi secara terbuka pada ibunya akan membuat ibu memahami setiap dinamika yang dihadapi anak terutama disaat anak memasuki usia remaja. 
Aspek kedua empati (empaty), merupakan kemampuan untuk merasakan setiap apa yang dialami atau dirasakan oleh orang lain tanpa anak yang selalu dapat merasakan apa yang dirasakan ibu dalam pikiran dan tindakannya serta anak dapat merasakan apa yang ibu alami seperti dia mengalaminya sendiri tanpa kehilangan identitasnya sebagai anak yang harus membantu dan bertanggung jawab terhadap dirinya. Ibu juga dapat merasakan apa yang sedang dirasakan anak sehingga muncul perasaan nyaman dan peduli dalam diri ibu dan anak. Rasa nyaman dan peduli yang dirasakan anak terhadap ibu akan membuat anak bisa menghadapi stresor dalam perkembangannya. Empati yang sama-sama dirasakan menambah kedekatan yang lebih akrab sehingga anak dapat menjadi pribadi yang peduli.

Aspek ketiga adalah dukungan, komunikasi yang dilakukan ibu dan anak lebih bersifat deskriptif daripada evaluatif sehingga anak didalam mengemukakan pikiran dan perasaannya tidak mengalami ketakutan. Sifat deskriptif akan lebih menyenangkan daripada sifat evaluatif. Ibu yang melakukan komunikasi dengan lebih bersifat evaluatif akan lebih banyak menyalahkan segala yang menjadi pikiran dan perasaan anak bila tidak sesuai keinginan ibu, sehingga anak merasa tidak dihargai dan tidak mendapatkan toleransi. Keadaan demikian akan membuat anak enggan untuk mencurahkan segala perasaan dan pikirannya.

Aspek keempat adalah sifat positif, komunikasi yang dilakukan ibu pada anak memiliki nilai-nilai perhargaan dan memuji apa yang disampaikan anak kepada ibu. Pujian tersebut dapat meningkatkan rasa percaya diri anak dalam mengemukakan pendapat yang dirasakan dan dipikirkan anak dan membuat anak lebih menghargai dirinya, dengan demikian anak merasa hidupnya lebih bermakna. Komunikasi yang dilakukan tanpa adanya sifat positif dari ibu akan membuat anak berpikir bahwa hidup yang dijalaninya tidak bermakna.

Aspek kelima merupakan aspek kesamaan (similarity), Komunikasi dengan kesetaraan tidak mengharuskan anak untuk selalu menerima dan menyetujui perkataan dan perilaku ibu. Secara umum, permintaan anak harus disampaikan secara sopan sehingga ibu dapat memahaminya sebagai suatu kebutuhan, bukan dengan cara menuntut ibunya, bagiibu tidak menampakkan superioritasnya sebagai orangtua yang berhak mengatur anaknya dan selalu menang. Kesetaraan yang dibentuk ibu dalam berkomunikasi kepada anak akan membuat anak memiliki teman yang baik untuk berbagi dalam segala hal selain teman di sekolah maupun teman di luar rumah. Anak akan selalu mendapatkan kebahagiaan dan mampu menjalin relasi dengan baik pada siapa saja sehingga membuat anak tidak merasa sendiri dan diabaikan. 


\section{Metode Penelitian}

Variabel dalam penelitian ini adalah depresi sebagai variabel tergantung dan variabel bebasnya adalah komunikasi ibu dan anak. Subjek penelitian ini adalah siswasiswi kelas XII Sekolah Menengah Kejuruan Negeri berjumlah 90 siswa, yang diambil dengan teknik cluster random sampling.

Data diperoleh dengan menggunakan skala depresi remaja dan skala komunikasi ibu dan anak. Setelah dilakukan uji coba alat ukur, didapatkan hasil sebagai berikut skala depresi pada remaja memiliki koefisien reliabilitasnya menjadi 0,872 dengan jumlah aitem 33, dengan rentang indeks daya beda aitem terendah $\left(\mathbf{r}_{\text {it }}\right)$ 0,247 (aitem no. 3) sampai yang tertinggi 0,605 (aitem no. 18). Skala komunikasi ibu dan anak memiliki koefisien reliabilitas alpha ( ) 0,929 dengan jumlah aitem 35 dengan indeks daya beda aitem terendah $\left(\mathbf{r}_{\mathrm{it}}\right)$ 0,301 (aitem no. 50) sampai yang tertinggi 0,727 (aitem no. 23).

\section{Hasil dan Pembahasan}

Hipotesis yang menyatakan bahwa ada hubungan yang negatif antara komunikasi ibu dan remaja dengan depresi pada remaja diuji dengan menggunakan koefisien korelasi product moment dengan bantuan program SPSS 16,0 for windows. Berdasarkan hasil analisis tersebut didapatkan $\left(r_{x y}\right)=-0,325$ dan probabilitas $\mathrm{p}=0,002(\mathrm{p}<0,01)$, hal tersebut menunjukkan bahwa terdapat korelasi negatif yang sangat signifikan antara variabel komunikasi ibu dan anak dengan depresi pada remaja.

Hasil analisis menunjukkan adanya hubungan negatif yang sangat signifikan antara variabel bebas $(\mathrm{X})$ yaitu komunikasi ibu dan anak dengan variabel tergantung (Y) yaitu depresi pada remaja, semakin baik komunikasi yang dilakukan ibu pada anak maka semakin kecil terjadinya depresi pada siswa, sebaliknya semakin kurang komunikasi ibu pada anak maka semakin besar terjadinya depresi pada siswa.

Sumbangan efektif $\left(\mathrm{r}^{2}\right)$ dari komunikasi ibu dan anak terhadap depresi pada remaja sebesar 10,5\%, sedangkan sisanya $89,5 \%$ dipengaruhi oleh faktor-faktor lain yang tidak diteliti misalnya pola asuh yang dilakukan orang tua pada anaknya, faktor keturunan yaitu anak yang memiliki orang tua depresi, kehilangan orang-orang yang dicintai, gaya hidup remaja yang tidak sesuai dengan kemampuannya, serta terbatasnya hubungan dengan teman sebaya.

Berdasarkan data deskriptif subjek dapat dikategorikan ke dalam tiga kategori 
yaitu rendah, sedang, dan tinggi. Kategorisasi subjek menunjukkan bahwa sebagian besar siswa kelas XII Sekolah Menengah Kejuruan Negeri melakukan komunikasi yang baik antara siswa dan ibu, hal ini dapat dilihat darinilai kategorisasi yang diperoleh tinggi yaitu sebesar $54,44 \%$. Sedangkan untuk depresi pada siswa kelas XII Sekolah Menengah Kejuruan Negeri terdapat dalam kategorisasi sedang yaitu sebesar 64,44\%. Siswa kelas XII Sekolah Menengah Kejuruan Negeri melakukan komunikasi yang baik antara ibu dan siswa sehingga mampu menekan terjadinya depresi pada siswa.

Salah satu yang mengakibatkan remaja mengalami depresi adalah keadaan stres berat yang dialami karena komunikasi yang tidak efektif antara satu dengan yang lain dalam hal ini antara ibu dan remaja (Rice, 1999). Komunikasi antara ibu dan anak adalah komunikasi yang melibatkan unsur-unsur penerimaan, kehangatan, dan kasih sayang sehingga membentuk saling pengertian antara ibu dan remaja (Hawari, 1991). Bagi remaja berkomunikasi dengan ibu di dalam keluarga tentang pengalaman sehari-hari adalah penting.

Komunikasi antara ibu dan anak lebih melibatkan unsur interpersonal sehingga tersampaikan dengan baik sesuatu hal yang menjadi keinginan dan pemikiran ibu seperti yang diungkapkan Durkin (1995) bahwa komunikasi anak dengan ibunya cenderung berkaitan dengan masalah interpersonal, sedangkan komunikasi dengan ayah cenderung berkaitan dengan persiapan anak menghadapi dunia luar. Dalam keluarga ibulah yang bersikap lebih menerima, lebih mengerti dan koperatif terhadap anak dibandingkan dengan ayah, meskipun ibu seperti juga ayah dapat menunjukkan otoritasnya bila persoalan-persoalan mengenai hal yang prinsip (Younis dan Smollar dalam Monks, dkk.1992).

Komunikasi yang dilakukan oleh ibu dan anak memiliki unsur-unsur penerimaan, kehangatan dan kasih sayang. Ibu sebagai figur yang paling intens melakukan komunikasi dengan anak lebih mengarahkan pembicaraan seputar permasalahan sehari-hari remaja. Dalam keluarga sendiri, ibu orang yang pertama menjadi media komunikasi bagi remaja. Hal ini dikarenakan orang yang paling berperan penting dalam pengasuhan anak sehingga ibu bisa memahami seluk-beluk perkembangan anak, terutama di masa remaja. Semakin pesatnya perkembangan yang dialami anak dimasa remajanya, masalah dan kesulitan banyak muncul dalam diri remaja. Bagaimana cara remaja mengatasi masalah, dapat menerima kekurangan pada dirinya, bagaimana remaja dapat memanfaatkan waktu dengan baik dan bersemangat dalam menjalani hidup penting dipahami remaja dengan cara berkomunikasi secara lancar, nyaman, dan akrab dengan ibu (Fuad, 2005). Rasa penerimaan, kehangatan, dan 
kasih sayang yang baik dari ibu akan membuat remaja bisa lebih terbuka dalam menghadapi masalahnya sehingga remaja tidak mengalami keadaan depresi.

\section{Simpulan}

Berdasarkan penelitian yang telah peneliti lakukan, didapatkan hasil adanya hubungan negatif yang sangat signifikan antara komunikasi ibu dan anak dengan depresi pada remaja. Hubungan negatif tersebut mengindikasikan atau memiliki arti semakin baik komunikasi yang dilakukan ibu pada anak maka semakin rendah depresi yang terjadi pada remaja, sebaliknya semakin kurang atau tidak baik komunikasi yang dilakukan ibu pada anak maka semakin tinggi depresi terjadi pada remaja.

Sumbangan efektif $\left(\mathbf{r}^{2}\right)$ darikomunikasi ibu dan anak terhadap depresi pada remaja adalah sebesar $10,5 \%$, sedangkan $89,5 \%$ dipengaruhi oleh faktor lain yang dapat memunculkan depresi pada remaja.

\section{Daftar Pustaka}

American Psychiatric Association. (2000). Diagnostic and Statistical Manual of Mental Disorders ( $4^{\text {th }}$ ed, text revision). Washington, DC : Author.

Anonymus. (2007). Depresi Pada anak dan Remaja. http/www. Anonymus-rublik kesehatan. Com. 27 Juli 2009.

Beck, A.T. (1985). Deppresion : Caused and Treatment. Philadelphia : University Of Pennsylvania Press.

Chaplin, C.P. (1997). Kamus Lengkap Psikologi. Jakarta : PT. Raya Grafindo Persada.

Cole, K. (1997). Crystal Clear Communication : Rahasia Kejernihan Komunikasi. Terjemahan (Sidhi Diah. S.) Jakarta: Elex Media Komputindo PT.

Dancey, J., dan Kenney, M. (1997). Adolescent Development. USA : Brown \& Benchmark Publisher.

De Vito, J.a. (1995). The International Communication Book. Seven Edition. New York : Haarper Colins College Publishers.

Durkin, K. (1995). Development Social Psychology, from Infancy to Old Age. 
Cambrige : Blackwell Publisher,Inc.

Fadillah. A, (2001). Pengertian Depresi Dalam Hakekat Sesungguhnya. http:// www.e-psikologi.com. 26 September 2008.

Fuad, F. (2005). Menjadi Orang Tua Bijaksana. Yogyakarta : Tugu Publisher.

Greenberger, D., \& Padesky, C.A. (2004). Manajemen Pikiran. Bandung: Penerbit Kaifa.

Hawari, D. (1991). Penyalahgunaan Narkotika, Zat Adiktif dan Asertifitas Komunikasi. Makalah (Tidak Diterbitkan). Jakarta.

Kartono, K. (2004). Patologi Sosial 3 (Gangguan-Gangguan Kejiwaan). Jakarta: Rajawali Pers.

Liliweri, A. (1997). Perspektif Teoritis Komunikasi Antar Pribadi Suatu Pendekatan Ke Arah Psikologi Sosial. Bandung: PT. Citra Aditya Bhakti.

Monks, F.J : Knors, A.M.P dan Haditono,S.R. (1992). Psikologi Perkembangan Pengantar Dalam Berbagai Bagiannya. Yogyakarta : Gajah Mada Universitas Press.

Panut, P. \& Ida, U. (1999). Psikologi Remaja. Yogyakarta : PT. Tiara Wacana.

Rice. 1999. Pengertian Depresi. http:/www.e-psikologi.pengertian psikologi.com. 6 Agustus 2008.

Santrock, J. W, (2003). Adolescence (Perkembangan Remaja). Jakarta : PT. Erlangga.

Steinberg, L. (2002). Adolescence, $6^{\text {th }}$ editor. New York : MC Grow Hill.

Supratiknya, A. (2002). Mengenal perilaku Abnormal. Yogyakarta : Kanisius.

Thabrany, R, \& Pujianto. (2002). Gangguan Psikis Pada Orang Normal. Makalah. Surabaya.

Vitahealt, (2003). Stroke. Jakarta : PT. Gramedia Pustaka Utama.

Wikipedia. (2008). Pengertian Komunikasi. http/www. Winkipedia-pengertian komunikasi. Com. 03 Maret 2009. 